\title{
The surge of Preferential Trade Agreements acrossin Asia: What is at stake?
}

\author{
Christian Milelli*
}

\begin{abstract}
Economists along with policy makers are generally viewing trade agreements as a "second best" process for trade expansion and economic growth on a global scale. The current surge of preferential trade arrangements on a bilateral basis, particularly in Asia, is somehow challenging such common view. The following paper is based on updated rough facts and put forward that the standard economic approach is a bit flawed. Obviously, the outcomes and prospects for Asian countries seem much more problematic insofar as power asymmetry and discrimination are embedded in these agreements.
\end{abstract}

\section{KEYWORDS : Asia, Preferential Trade Agreement, Regionalization}

Nowadays, Asia is highlighting a surge of Preferential Trade Arrangements (PTAs), incorrectly called Free Trade Agreements, as a new experience. As a result, Asia has been propelled toat the forefront of a more general phenomenon which started in the 1980s, inflated at the beginning of the 1990s and ballooned even more rapidly picked up speed since 1995. So far, more than 300 PTAs have been reported notified to the WTO with more than half in force. Beyond their diversity these arrangements have in common that they are both a bilateral and preferential incline.

However, the current wave is not a new phenomenon. In the 1950s and 1960s there were similar waves but toon a lesser extent around the European construction. Likewise, it's not an autonomous phenomenon but rather endogenous to the ongoing trade liberalization process: the GATT/WTO charter makes explicit provisions for them. But their scope largely exceeds eliminating tariff and non-tariff barriers - which were their raison d'être at the beginning.

The main reason behind this new drive is to be found in the difficulties and frustrations to finalize the most recent multilateral trade negotiations (1986-1994). So far, these rounds of negotiations have been a powerful and undeniable driver for the liberalization and the continuous expansion of international trade. Since 1947, the average

Submission Date : 10/6/2005 Acceptance Date : 12/5/2006

"Corresponding Author : Professor, University of Paris 10, EconomiX, 200 avenue de la Republique, 92001 Nanterre Cedex, France, E-mail:christian.milelli@u-paris10.fr 
ad valorem tariffs on industrial goods in developed countries have been dramatically reduced from 40 percent to less than 4 percent; nevertheless, agricultural products; trade has not achieved such a goal due to protectionist policies ${ }^{1}$ of industrialized nations. Moreover, the WTO which succeeded to the GATT in 1994 is currently made up of nearly 150 members with disparate views; decisions need time due to consensus rule, coalition games, and an agenda with a continually extended scope : almost ten years were required to finalize the Uruguay round.

Equally important was the increasing US support for PTAs after the failure of the Seattle ministerial conference in 1999; in sharp contrast with the 1950s and 1960s, when the US trade administration was strongly opposed to any such arrangement. For Krugman (1991) the waning of the US capacity and will to defend trade multilateralism is of main importance.

As a result, bilateralism has become an alternative to multilateralism, and flexibility and speed are increasingly put forward by its promoters; but it is also a vector of proliferation for preferential arrangements. The ongoing upsurge of PTAs through Asia challenges the global trade architecture built on the non-discriminatory principle or weakens any comprehensive regional integration scheme. ASEAN cohesiveness and its fledgling identity as the regional grouping are threatened by the growing rivalry between China, Japan, and South Korea, and to some degree India.

\section{I . Definition and scope}

\subsection{Definition}

For the sake of clarity, let's recall to some basic definitions and draw a typology. Since the pioneering work of Bela Balassa (1962), PTAs are generally viewed as the first stage of an economic integration process which can result after several sequences to a truly political union (Figure 1). PTA members reduce tariffs along with non-tariffs barriers ${ }^{2}$ among themselves but keep their original tariffs against the rest of the world, i.e. there is no common external tariff as in Customs Unions. Free Trade Agreements or FTAs are the extension and natural outcome of the previous ones wherein each member dismantles totally trade barriers among them, but keep their former tariffs with non-members countries. Asia is largely concerned by PTAs due to the novelty of the phenomenon and the will of most countries to retain some independence in trade policy toward nonmembers.

Interestingly, PTAs, FTAs and Custom Unions are called Regional Trade Agreements in the WTO terminology, whereas in the Belassa view they are embodied in a first tier denominated shallow integration.

These arrangements concern either countries of similar development level endowed with comparable resources - mainly developed countries - or countries with different

\footnotetext{
${ }^{1}$ Such as megatariffs, domestic support to farmers, market access restraints and export subsidies.

${ }^{2}$ Quotas, anti-dumping duties, countervailing measures and safeguard measures.
} 
development level endowed with distinct resources. They also concern agreements between countries and regional groupings (China-ASEAN or Japan-ASEAN agreements). Lastly, they are not limited to a specific region, taking into account propinquity, but increasingly involve countries from distant regions (see agreements concluded between South Korea and Chile, or Japan and Mexico).

In the economic literature, PTAs or FTAs are still regarded as nearly identical whereas in the real world heterogeneity is the rule; the academic interest is focused on trade effects stemming from tariffs reductions with the perspective of welfare improvement along with the growth of international trade even if a minority strand of research emphasizes strategic and political aspects resulting from widespread dissemination of such arrangements in the international arena.

Figure 1: The route to the economic integration

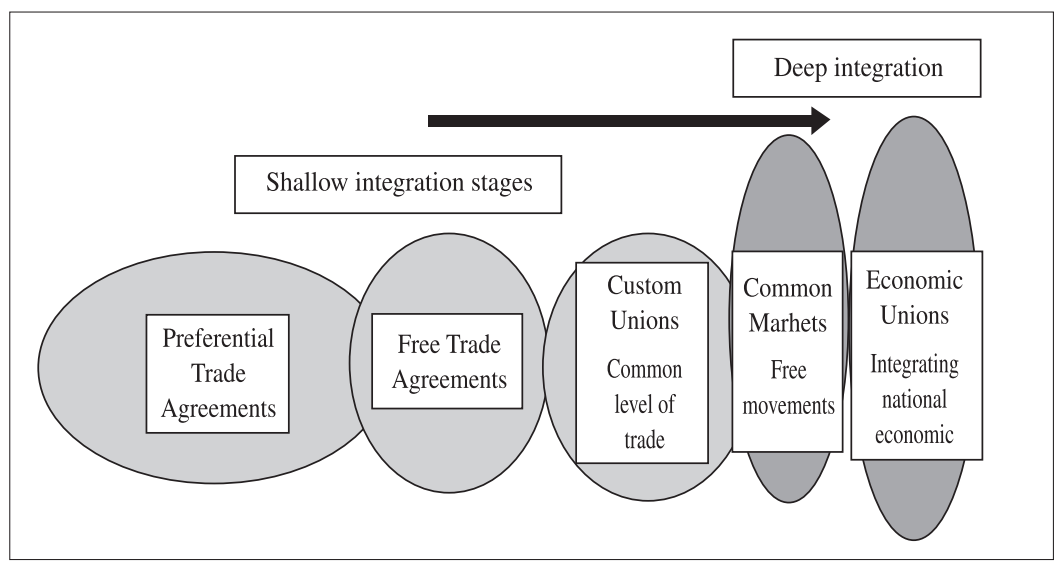

Source : from B. Belassa

\subsection{Scope}

PTAs are at odds with the WTO first article known as the unconditional most-favoured nation principle, which stipulates that every trade advantage that a member gives to any country must be extended, immediately and unconditionally, to all other members. Historical reasons explain this peculiarity: at the beginning, the treaty setting up the GATT had to include the British Commonwealth which was a free trade area. Consequently, a derogation of the non-discrimination principle was introduced in the founding charter (Article XXIV), and thereafter endorsed by the WTO.

To date, the WTO has three provisions allowing trade preferences on a reciprocal basis $^{3}$ :

i/ since 1948, the Article XXIV ( $§ 4$ to 10) provides an exception for free trade

${ }^{3}$ There are also schemes like the Generalized System of Preferences which permit to grant trade preferences on an unilateral basis. 
areas and customs unions which discriminate against other GATT members. This provision was updated in 1994. It is solely by this measure that developed countries can enjoy trade preferences; the European Economic Community and NAFTA were both based on this dispensation. Moreover, any arrangement between developing countries and developed ones is based on it. But these agreements must meet specific conditions, such as transparency and neutrality against non-members, and they particularly should apply to "substantially all trade" for a reasonable length of time. What is meant by substantial? The GATT article is helpless as the precise definition does not exist. However, if we refer to EU documents, over 90 percent of "all trade" would have to be completely free. And, as long as PTAs do not violate the provisions of the WTO, they can include a wide range of arrangements; likewise, they can discard contentious matters as specific farm products: for example, rice was excluded at the onset of trade negotiations between Thailand and Japan;

ii/ since 1979, the "Enabling Clause" allows less-developed countries to agree for mutual reduction or elimination of tariffs and non-tariffs barriers on products imported from one another through bilateral or regional arrangements. These requirements are more flexible than those contained in aforementioned Article XXIV since, for example, they permit the exchange of preferences on a sub-set of products, and the partial reduction, rather than elimination, of trade barriers. Agreements notified under the "Enabling Clause" have merely to be formally notified to the WTO. They are part of a more general approach promoting differential and more favourable treatment for those countries as well as the acknowledgement of a non-reciprocity principle in trade negotiations. The ASEAN Free Trade Agreement (AFTA) and the MERCOSUR/MERCOSUL are based on this provision.

iii/ and, since 1994, the Article V from the General Agreement on Trade in Services (GATS) supplies an exception to the most-favoured nation principle. This provision was included in the latest agreements, e.g. between Australia and Singapore (2003), and between Chile and South Korea (2004).

Furthermore, the latest PTAs tend to include "Singapore issues" (investment, competition policy, trade facilitation, and transparency in government procurements). For example, if the facilitation of customs procedure and documentation requirement has long been pointed out as a common objective for both developed and developing countries, to move forward it still requires substantial technical assistance to developing countries in order to strengthen their fledging administrative capacities. More generally, these issues have not yet been approved by the WTO members on a whole ${ }^{4}$.

Finally, PTAs occasionally include provisions about harmonization or mutual recognition of technical standards, electronic commerce promotion... and even political and security aspects which are not at all related to trade liberalization! If the former is rather beneficial for trade expansion the latter is much more problematic due

${ }^{4}$ Actually, they have been rejected during the fifth Ministerial Conference held in Cancun in 2003. 
paradoxically to the lack of transparency (for example when military interests are at play) or to very sensitive issues, such as national sovereignty.

To sum up, the capacity of PTAs to continuously expand their scope along with their customization explains the diversity of their wording (comprehensive economic cooperation, closer economic partnership...), but the current proliferation of such arrangements, notably in Asia, is a serious challenge to the multilateral framework, and also a new basis for national rivalry.

\section{II . The Asian drive}

It has to be reminded that the most important part of PTAs is still located in Europe with 100 in force in 2004 for a world total of 150. Until the end of the 1990s, Asia has been lagging far behind Europe, and even South and Central America.

However, nowadays the trend is clearly shifting to Asia, and once again a catchingup process is somehow at play (Table 1).

Table1: Breakdown of Preferential Trading Arrangements already in force or signed in Asia (May 2005)

\begin{tabular}{|c|c|c|c|}
\hline $\begin{array}{l}\text { Country } \\
\text { Partners }\end{array}$ & Status & Date & Scope \\
\hline \multicolumn{4}{|l|}{ India*: } \\
\hline ASEAN & signed & 2003 & general framework \\
\hline Thailand & signed & 2003 & general framework \\
\hline \multicolumn{4}{|l|}{ China: } \\
\hline ASEAN & in force & 2003 & general framework \\
\hline Thailand & signed & 2002 & Early Harvest Programme for some agricultural products \\
\hline Australia & signed & 2003 & trade and economic framework \\
\hline New-Zealand & signed & 2004 & trade and economic cooperation \\
\hline \multicolumn{4}{|l|}{ Korea: } \\
\hline Singapore & signed & 2005 & gradual elimination of tariffs on goods and services \\
\hline Chile & in force & 2004 & gradual elimination of tariffs on goods and services \\
\hline \multicolumn{4}{|l|}{ Japan: } \\
\hline Philippines & in force & 2006 & \\
\hline Singapore & in force & 2002 & restraints on labor mobility \\
\hline Vietnam & signed & 2003 & comprehensive agreement \\
\hline ASEAN & signed & 2003 & general framework for investment \\
\hline Mexico & in force & 2005 & general framework restraints on some agricultural products \\
\hline \multicolumn{4}{|l|}{ Singapore: } \\
\hline Japan & in force & 2002 & comprehensive agreement \\
\hline Australia & in force & 2003 & $\begin{array}{l}\text { comprehensive agreement exceeding current commitments at } \\
\text { the WTO }\end{array}$ \\
\hline
\end{tabular}




\begin{tabular}{|c|c|c|c|}
\hline $\begin{array}{l}\text { Jordan } \\
\text { New-Zealand } \\
\text { USA }\end{array}$ & $\begin{array}{l}\text { signed } \\
\text { in force } \\
\text { signed }\end{array}$ & $\begin{array}{l}2004 \\
2001 \\
2003\end{array}$ & $\begin{array}{l}\text { full liberalization of goods and services trade } \\
\text { comprehensive agreement } \\
\text { comprehensive agreement }\end{array}$ \\
\hline $\begin{array}{l}\text { Philippines: } \\
\text { Japan }\end{array}$ & in force & 2006 & restraints on labor mobility \\
\hline $\begin{array}{l}\text { Thailand: } \\
\text { China } \\
\text { India } \\
\text { Australia } \\
\text { Bahrain } \\
\text { Peru }\end{array}$ & $\begin{array}{l}\text { in force } \\
\text { signed } \\
\text { in force } \\
\text { signed } \\
\text { signed }\end{array}$ & $\begin{array}{l}2003 \\
2003 \\
2005 \\
2002 \\
2003\end{array}$ & $\begin{array}{l}\text { Early Harvest Programme } \\
\text { partial agreement } \\
\text { gradual elimination of bilateral tariffs barriers on goods } \\
\text { gradual elimination of bilateral tariffs barriers on goods } \\
\text { partial liberalization }\end{array}$ \\
\hline
\end{tabular}

"Signed Free-Trade Agreements with Bhutan and Nepal giving their goods free access to the Indian market, and with Bangladesh (concessionary custom duties)

Source: WTO

\subsection{The causes of the Asian delay}

Here, two main factors stand out.

First, is the lack of an institutionalized process for regionalization despite ASEAN. There is convincing evidence that PTAs were fuelled in Europe by the integration process along with the enlargement perspectives. To some extent, Asia's late coming is not only due to the lack of political will from Asian leaders but also to the US opposition to any real economic cooperation on a regional basis (Hamilton-Hart 2003). Although the Asia Pacific Economic Cooperation (APEC) group with US membership was set up in 1989, the subsequent East Asian Community project advocated by the Prime minister of Malaysia, and the Asian Monetary Fund proposed by the Japanese Prime minister were vehemently opposed by the United States, and they failed.

Second, up to the year 2000, the strong backing for the multilateral agenda highlighted by the Japanese authorities was notoriously, and they have been reluctant to abandon the multilateral framework which had been beneficial for Japanese firms. The same is true for South Korean authorities.

\subsection{The catching-up process}

The proposition to the ASEAN leaders, to implement a FTA for 2011, proposed by China after joining the WTO, has ignited the Asian drive. Although not mentioned in official reports, this initiative was a "wake up" call for Japan, and therefore fuelled a "bandwagon" effect through Asia with each country wanting to get on board and not be excluded ("me too" attitude).

In the same time, the Asian frenzy for PTAs was stirred by political-economy motives resulting from the interplay between sectors likely to gain from the set-up of such 
arrangements, and others that would be adversely affected by them. But such balance is inherently unstable and rife with conflict between interest-group lobbies. This is particularly true for Japan where the interests of the business community are growingly coalescing with those of lawmakers and policy makers, as farmers are losing their political clout due to their aging.

Governments have a preference for PTAs as the stakes and the related outcomes can be better explained to the public. Besides, those negotiations are often used as a lever to stir domestic adjustments and implement reforms. However, in some cases, the process is not smooth and is blocked by national assemblies. For example, the most protected sectors such as agriculture in South Korea and Japan are strongly opposed to those deals. It is hardly surprising that, in 2003, the endorsement of a trade agreement both between Mexico and Japan, and Chile and South Korea collapsed.

\subsection{The purposes followed by major countries}

We focus on large countries - i.e. with significant size market - which are already well engaged in FTAs negotiations and implementation. Singapore and Thailand are both at the forefront of the Asian drive; South Korea is still behind Japan despite a current catchingup; whereas India is just taking initiatives in this field (Table 1).

- $\quad$ China has an obvious interest in following the WTO discipline to allow relatively unhindered access to the large EU and North American markets to fuel export growth. But, in its periphery, China can exert power in regional and/or bilateral negotiations to get preferential access to expanding markets (Mallon \& Whalley, 2004). As a large manufactured goods exporter, China seeks to stress preferential access in these areas through tariffs reductions. The agreements already concluded or still in progress are; nevertheless they have in common a general statement, and they lack explicit process to solve trade disputes.

- $\quad$ The United States follows a policy combining three levels (multi-layered): multilateral, regional and bilateral. Under the Trade Promotion Authority (also known as "fast track") the administration negotiates trade agreements and the Congress restricts itself to approve or reject a negotiated trade agreement, within strict time limits and without amendment. The scope of policy exceeds trade aspects as the United States is the champion of arrangements covering a broad spectrum with particular stress on services liberalization and intellectual property rights enforcement. In this regard, there is clearly a strategic dimension based on national interest which includes the following features (Feinberg, 2003):

- asymmetric reciprocity due notably to market power that advantageously opens foreign markets for US traders and investors;

- establishment by the US Trade Representative of new precedents or models to use as benchmarks in future trade; called competitive liberalization.

- rewarding and supporting domestic market-oriented reformers as was the case 
for Mexico, and advancing local democratic institutions;

- And, reaffirming and strengthening US security interests through strategic partnerships.

After demonstrating an interest in the Asian zone, particularly the ASEAN countries, the US administration interest is tilting to South America ${ }^{5}$. And if the economic impact of PTAs on US GDP has been quite small - as barriers to trade and investment flows are already low in most domestic sectors - PTAs have been elevated into the centre of national trade strategy and supported by a broad-based coalition of bureaucratic interests.

- Japan is mimicking the US multi-layered approach for its trade. The regional priority is Asia, particularly ASEAN, after the initiative taken by China in 2002. Farm products are still put aside in order to protect Japanese farmers, but contrary to the USA or the EU, trade negotiations are not a smooth process due to a turf war between Japanese administrations.

\section{What is at stake? Some potential effects}

The identification and the measure of the PTAs effects are not an easy task. These difficulties are yet increased by the novelty of the phenomenon in Asia and its current instability; moreover, it is particularly difficult to distinguish what has been signed from what is effectively in force inasmuch as many agreements are more ambitious in aspiration than in implementation.

Nevertheless, it's possible in an exploratory attempt to put forward some hypotheses on the potential effects drawn from economic theory and prior experiences along with initial results. Three major effects can be checked off.

Firstly, they affect trade flows and foreign direct investment (FDI). The economic literature is still largely focused on trade flows, and a reading of the current agreement contents reveals that foreign investment has become a top priority on government agendas. Moreover, in the mid to long term these agreements can have implications for the economic growth performance of members by raising the incentive to innovate through technological spillovers, pro-competitive effects, andor reduction of redundancies in R\&D activities.

Secondly, they impact international relations by reflecting significant power

${ }^{5}$ As part of the Dominican Republic-Central American Free Trade agrement, the US administration signed in 2004 agreements with Costa Rica, El Salvador, Guatemala, Honduras, Nicaragua and the Dominican Republic; in parallel, it opened negotiations with three members of the Andean Community (Colombia, Ecuador and Peru) along with Panama. And, despite troubled negotiations, the ambitious "Free Trade Area of the America" encompassing all countries of the the Western Hemisphere except Cuba is still on the agenda. 
asymmetries. PTAs ared bilateral in nature and involve face-to-face bargaining. By implication, related costs and time spent could be a burden for the scare negotiating resources of most developing countries.

Thirdly, they directly affect the multilateral trading system. A large body of literature has already addressed this question and therefore we shall not discuss this point.

\subsection{Trade effects}

The effect of PTAs on Asian trade is still negligible when compare to other regions as Western Europe (EU) ${ }^{6}$, North America (NAFTA) or even South America (MERCOSUR). To date, no Asian PTA deals with significant trade flows except the project between Japan and South Korea which came to a standstill during the 2004 (see Table 2). And when PTAs are in place its coverage could be limited. For example, less than 10 percent of intra-ASEAN trade is under the ASEAN Free Trade Area's common preferential tariff scheme (The Economist, 2004).

Table 2: Share of exports related to PTAs finalized by major Asian countries (in US\$ Billion)

\begin{tabular}{c|cc|c|c}
\hline Country & \multicolumn{2}{|l|}{ Exports to FTA partners (A) } & Total exports (B) & $\begin{array}{c}\text { Exports share related to } \\
\text { PTAs in \% (A/B) }\end{array}$ \\
\hline South Korea & Chile & 0.5 & 192.7 & $2.6 \%$ \\
& Singapore & 4.6 & & \\
\hline \multirow{3}{*}{ Japan } & Singapore & 14.9 & & $5.8 \%$ \\
& Philippines & 9.0 & 473.9 & \\
& Mexico & 3.6 & & $6 \%$ \\
\hline China* & ASEAN & 26 & 438.2 & \\
\hline
\end{tabular}

"Actually, through the "Early Harvest Programme" only trade of some basic agricultural products would be fully liberalized by 2006 .

Source : from Hyun \& Hong (2005)

It has to be remembered that these trade arrangements primarily concern tariffs and non-tariffs reductions. The insights provided by Jacob Viner's seminal contribution in 1950 are still valid: if PTAs and FTAs entail significant trade effects one cannot draw straightforward welfare effects due to the possibility to bring about "trade creation" or "trade diversion" - i.e. PTAs may augment intra-bloc trade by diverting trade away from non-member economies. This ambiguous feature has been underlined by later researches (Grossman \& Helpman, 1995; Krishna, 1998) using political-economy constructs. Hence, they have showed that trade diversion could be an important motive leading to PTAs.

\footnotetext{
${ }^{6}$ To date, more than 65 percent of intra-European trade is concerned.
} 
Empirical approaches suggest that Asian PTAs have enhanced regional trade (Clarete, Edmonds \& Wallack, 2003), but the effect is less important than in other regions which can arguably be explained by the novelty of the phenomenon. For example, under the "Early Harvest Programme," Thailand's exports of vegetables increased, in the first quarter of 2004, by 38 percent, and fruits by 80 percent (Ankietwicz \& Whalley, 2004), but the overall trade share is still low; the previous programme covered 1.2 billion of dollars in 2003, corresponding just to 1.6 percent of trade flows between ASEAN and China (Inama, 2005).

Due to low average tariffs (10 percent), except in some Asian countries and for megatariffs, rules of origin - which are an important component of PTAs ${ }^{7}$ - constitute a true challenge ${ }^{8}$, even when their economic rationale is to prevent the import of any particular commodity from entering through the country with the lowest duty on the item in question and being re-exported to other member countries.

For example, rules of origin were put forward by the Japanese administration in the first trade talks with Mexico. Simulations had showed that NAFTA had adverse effects on Japanese exports to Mexico: from 1994 to 2000, the share of Japanese imports in the overall Mexican imports decreased continuously from 6 percent in 1994 to 3.5 in 2000, corresponding to a yearly export gap of around 400 billion yen.

But the setting up of rules of origin can be problematic at least for two reasons. First, a strict application can induce protectionism against non-member countries, hence it diverts trade. Second, the continuous increase of PTAs can entail a bundle of confusing and overlapping bilateral deals - known as a "spaghetti bowl" syndrome - constituting a nightmare for the various actors, custom officers and private sector that have to implement, to enforce or to comply with those regulations.

To sum up, it is still too early to gauge the effects of PTAs and particularly the rules of origin on trade flows through Asia.

\subsection{Effects on FDI localization}

Asian trade was multiplied by 2.5 during the 1990 decade, inward FDI flows were multiplied by 7 for the same period. And in the case of China, the gap was even more dramatic: here, international trade was mutiplied by 4 whereas FDI inflows increased by a factor of 11 !

So it is not surprising that incentives to attract FDIs are the most common component of Asian PTAs. In fact, it is the first motive for developing countries ${ }^{9}$ to embrace the current wave of FTAs, and start negotiations with developed countries which are the main providers of FDI flows.

Here, central commitments are national treatment, most-favoured nation treatment

\footnotetext{
${ }^{7}$ They specify a certain proportion of the value - added that must have within union - origin to quality for duty - free status in the PTAs. In this regard, rules of origin tooh up 200 pages in the NAFTA agteement.

${ }^{8}$ Indeed, they also entail a political economy dimension as interest groups can exploit them for their own ends.
} 
for foreign investors alongside provisions relating to expropriation, compensation, and repatriation of earnings (Banda \& Whalley, 2005).

To date, PTAs have had very little influence on the investment localization. But as more PTAs are put forward the situation may be changing and affect the whole production sharing dynamic across Asia.

Accordingly, it's rather a tricky undertaking to size up the effects of PTAs provisions on foreign investment, because they are enmeshed with others effects resulting, for example, from tariffs reduction. If tariffs are retained, an enterprise will invest overseas by setting up a subsidiary company in order to supply a protected market (tariff jumping), instead of exporting and paying tariffs. A PTA with this country automatically makes the market less protected, hence reducing its attractiveness to invest. ${ }^{10}$ An enterprise can also invest overseas in order to reap various comparative advantages regarding different manufacturing processes: semi-final goods or components need to be exported to other plants, operations which incur tariffs. Therefore, by reducing these costs a PTA can increase foreign investment, and trans-national corporations could enlarge their international division of labour. But these arrangements can have adverse effects by raising transactions costs (rules of origin requirements), and encouraging concentration on few localisations.

The national origin of FDI is also a key element as the impact depends on whether the supplier country is part of the trade agreement. In the case of NAFTA, FDI from the United States and Canada have been significantly increased in Mexico after 1994 (Waldkirch, 2001); thus, the creation or the extension of preferential trade zones can divert FDI, and this could be particularly problematic for countries with high manufacturing costs.

\subsection{Effects on international relations}

It is well known that the international stage encompasses substantial power games effects where large countries enjoy bargaining power on account of their economic size and political clout. The wave of bilateralism across Asia through PTAs carries such risks even if talks and negotiations conducing to trade agreements are in line with the WTO framework.

It has to be reminded, that most Asian countries have more benefited from the multilateral negotiations through the GATT/WTO system than through face-to-face negotiations with the United States. Indeed, in multilateral arena Asian countries can better share and advocate common interests through a mutually advantageous approach.

But the current multilateral framework is marred with various difficulties. The entire system is challenged by the necessity to keep on with the expansion of international trade - particularly, to tackle pending issues such as the liberalization of agricultural products' trade, or to grasp new ones as the enhancement of trade facilitation - and a decision-taking

\footnotetext{
${ }^{9}$ The world Trade Report(2003) suggests that countries join PTAs to attract FDI.

${ }^{10}$ But other factors can be at play as market size and therefore reverse the causal relationship.
} 
process which is growingly time-consuming. In some extent, the situation is similar to the EU one with difficulties to move ahead and embrace its political agenda.

\section{IV . Are Asian PTAs enhancing regional trade and a step to economic integration?}

The ongoing proliferation of PTAs across Asia, let alone with other regions, requires not minimizing the risks for regional trade along with economic integration. Some recommendations can be drawn from the initial results.

First, inasmuch as PTAs are partial, fragmentary, heterogeneous, and above all uncoordinated, it stands to reason to seek harmonizing the different rules and regulatory codes attached to the various Asian PTAs. Obviously, the lack of cooperation is crucial and the following question has to be raised: which institution or framework would be in charge to tackle the task? Arguably, the logical candidate is the "ASEAN plus three" forum whose members carry the bulk of Asia's trade. However, historical and strategic motives, particularly the growing rivalry between Japan and China, impaired the organization taking effective initiatives with convincing political will.

In our view the main challenge for Asian countries is to keep on pace with a trade-led growth regime based on a manufacturing sharing configuration on a trans-regional base. Accordingly, it will be particularly appropriate to have PTAs focusing on trade environment. Indeed, due to the specificity of Asian trade (intra-regional flows of intermediate goods and strong FDI-trade nexus) the following undertakings would have a great impact on Asia trade: trade facilitation (notably the easing of customs procedure and documentation requirements), the promotion of cross-border investments, and to some extent, the liberalization of people mobility across borders from geographically contiguous countries.

To be effective this drive has to get strong political support, and major Asian countries should be the promoters and advocates of this route toward regional trade integration. In addition, these commitments could be more easily endorsed by the WTO in coming negotiations.

In parallel, it would be appropriate to largely disseminate general guidelines supporting this orientation, and multinational bodies like the Asian Development Bank could endorse this helpful job.

Second, PTAs could also impact significantly economic integration. To date, Asia has no regional undertaking apart from ASEAN, but ASEAN is quite different from the EU or NAFTA. Indeed, when one gives closer scrutiny to ASEAN, it appears to be basically a formal grouping of altogether heterogeneous countries. Of course, regional integration was given a new impetus during the Bali summit in October 2003 - by putting the year 2020 as the deadline for implementing a common market. In fact, the aim was to speed up the ongoing PTAs, which had yet to be implemented (Stubbs, 2000). Trade barriers are still there along with sizeable hurdles for investment and people mobility: a sole market for ASEAN countries is not for today. Such a delay is largely due to a lack of political leadership and economic interdependency, along with inadequate designs and drafting modalities for effective trade liberalization (Inama, 2005). As said previously the 
liberalization process entailed by AFTA is very slow.

As a result, the rising tide of PTAs across Asia could shape the whole regional economic dynamism. The "stylized facts" approach which had pointed out a two-hub (China and Japan) or a multiple-hub (ASEAN, China, Japan and South Korea) emerging design highlighting the chaotic and uneven path to regional integration.

Here, the recommendations to be made are more challenging. They require an unequivocal commitment by large countries to facilitate trade integration of lessdeveloped countries, not to mention the poor ones. Likewise, major countries must restrain to embark in a race for strategic trade policy, and rather promote cooperation in multilateral and regional arena.

Developing countries on their own must cooperate, exchange information and experiences, and pool scare administrative resources. They must also be cautious not to be involved in binding rules, and favour cooperative arrangements with safeguard measures.

After all, an alternative option to economic integration could be to advance financial integration at the region level. For example, the expansion of current initiative such as the "Asian Bond Market initiative" toward more financial linkages could be of great interest due to the large amount of foreign currency reserves held by Asian central banks. By doing so, Asian countries would modify the sequence of the stepping stones conducing to economic integration(Figure1) and would embark Asia on a more direct path toward integration like Europe's. 


\section{References}

Antkiewicz, A., Whalley, J. (2004), China's new regional trade agreements, NBER Working paper no. 10992.

Balassa, B. (1962), The theory of economic integration, London: Allen \& Unwin.

Banda, B., Whalley, J. (2005), Beyond goods and services: competition policy, investment, mutual recognition, movement of persons, and broader cooperation provisions of recent FTAs involving ASEAN countries, NBER Working paper no. 11232.

Clarete, R., Edmonds, C., Wallack, J. (2003), Asian regionalism and its effect on trade in the 1980s and 1990s, Journal of Asian Economics 14 (1): 91-129.

Feinberg, R. (2003), The political economy of US FTAs, The World Economy 26 (7): $1019-40$.

Grossman G., and Helpman, E. (1995), The politics of free trade agreements, American Economic Review 85: 667-90.

Hamilton-Hart, N. (2003), Asia's new regionalism: government capacity and cooperation in the western Pacific, Review of International Political Economy 10 (2): 222-45.

Hyun, J.-T., Hong, J.-Y. (2005), Free Trade Agreements in East Asian countries: characteristics and remaining tasks, International Trade and Logistics, Corporate Strategies and the Global Economy Conference, Le Havre, September 28-29.

Inama, S., (2005), The Association of South East Asian Nations - People's Republic of China Free Trade Area: negotiating beyond eternity with little trade liberalization? Journal of World Trade 39 (3): 559-79.

Krishna, K. (1998), Regionalism and multilateralism: a political economy approach, Quarterly Journal of Economics 113 (1): 227-51

Krugman, P., (1991), Is bilateralism bad? in: Helpman \& Razin (eds), International trade and trade policy, Cambridge: MIT Press.

Mallon, G., Whalley, J. (2004), China's post accession WTO stance, NBER Working paper no. 10649.

Milelli, C. (2005), "L'essor des accords de libre-échange en Asie", Problémes économiques no. 2873.

Panagariya, A. (2000), Preferential trade liberalization: the traditional theory and new developments, Journal of Economic Literature 38 (2): 287-331.

Stubbs, R. (2000), Signing on to liberalization: AFTA and the politics of regional cooperation, The Pacific Review 12 (2): 297-318.

The Economist (2004), Free Trade in South-East Asia, July 29.

WTO (2003), Statistics, Geneva. 